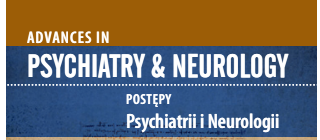

Correspondence to/

Adres do korespondencji:

Dariusz Kotlęga

Department of Neurology

Pomeranian Medical University

in Szczecin

1 Unii Lubelskiej St.

71-252 Szczecin, Poland

phone: +48914253251

e-mail: dkotlega@poczta.onet.pl

Submitted/Otrzymano: 06.03.2019

Accepted/Przyjęto do druku: 06.03.2019

\section{DETECTION OF STROKE RISK FACTORS OVER THE DECADE IN THE POLISH POPULATION OF ISCHEMIC STROKE PATIENTS}

WYKRYWALNOŚĆ CZYNNIKÓW RYZYKA UDARU NA PRZESTRZENI DEKADY W POLSKIEJ POPULACJI PACJENTÓW Z UDAREM NIEDOKRWIENNYM MÓZGU

\author{
Dariusz Kotlęga', Monika Gołąb-Janowska', \\ Agnieszka Meller', Wioletta Pawlukowska², \\ Przemysław Nowacki ${ }^{1}$
}

'Department of Neurology, Pomeranian Medical University, Szczecin, Poland 2Department of Medical Rehabilitation and Clinical Physiotherapy, Pomeranian Medical University, Szczecin, Poland

'Katedra i Klinika Neurologii, Pomorski Uniwersytet Medyczny w Szczecinie, Polska 2 Zakład Rehabilitacji Medycznej i Fizjoterapii Klinicznej, Pomorski Uniwersytet Medyczny w Szczecinie, Polska

\begin{abstract}
Purpose: Stroke risk factors are divided into modifiable and non-modifiable. As much as $90 \%$ of stroke incidence is provoked by modifiable risk factors. The aim of the study was to assess the pre-stroke risk factors' detection in the population of Szczecin during a decade.

Methods: Retrospective analysis of consecutive ischemic stroke patients, including transient ischemic attack (TIA), hospitalised between 2003 and 2005 (group I, $n=1524$ ) as compared to the period from 2013 to 2014 (group II, $n=869$ ).

Results: The mean age of population in group I was 70 years as compared to 74 in group II $(p<0.001)$. The pre-hospital detection of the main ischemic stroke risk factors increased significantly, which refers mainly to hypertension, coronary heart disease, atrial fibrillation, diabetes and dyslipidemia; however, acute coronary syndrome remained at the same level. The frequency of in-hospital detection decreased in diabetes and dyslipidemia with no change of hypertension and coronary heart disease. Atrial fibrillation was the only analysed risk factor that was more frequently detected both pre- and in-hospital after 10 years. The frequency of excessive drinking and smoking decreased throughout the decade. There were no changes in neurological deficit and mortality during the hospitalisation. TIA was more often observed in group II.

Conclusions: During a decade, we observed an improvement in detection of the main modifiable stroke risk factors, including reduction in the habits frequency that lead to increase in the age at stroke onset. The detection and management within the risk factors in the primary prevention of stroke in the group of Polish stroke patients improved in the analysed period.
\end{abstract}

Key words: risk factors, stroke, epidemiology, prevention.

\title{
Streszczenie
}

Cel: Czynniki ryzyka udaru dzielą się na modyfikowalne i niemodyfikowalne. Wystąpienie udaru mózgu jest w 90\% związane z modyfikowalnymi czynnikami ryzyka. Celem pracy była ocena wykrywalności czynników ryzyka udaru w populacji miasta Szczecina na przestrzeni dekady.

Metody: Retrospektywnej analizie poddano kolejnych pacjentów z udarem mózgu oraz przemijającym atakiem niedokrwiennym (transient ischemic attack -TIA) hospitalizowanych w latach 2003-2005 (grupa I, $n=1524$ ) w porównaniu z latami 2013-2014 (grupa II, $n=869$ ). 
Wyniki: Średni wiek badanej populacji w grupie I wyniósł 70 lat, natomiast w grupie II - 74 lata $(p<0,001)$. Wykrywalność głównych czynników ryzyka przed wystąpieniem udaru mózgu znacznie się zwiększyła. Odnosi się to do nadciśnienia tętniczego, dyslipidemii, migotania przedsionków, cukrzycy oraz choroby niedokrwiennej serca, przy czym wykrywalność ostrych zespołów wieńcowych pozostała na stałym poziomie. Wykrywalność czynników ryzyka podczas hospitalizacji zmniejszyła się w zakresie cukrzycy i dyslipidemii, natomiast pozostała bez zmian w przypadku nadciśnienia tętniczego i choroby niedokrwiennej serca. Migotanie przedsionków stanowiło jedyny zidentyfikowany czynnik, którego wykrywalność wzrosła zarówno w okresie przedszpitalnym, jak i podczas hospitalizacji na przestrzeni dekady. Częstość nadmiernego spożycia alkoholu i palenia papierosów obniżyła się w ciągu dekady. Nie odnotowano różnic w zakresie stopnia deficytu neurologicznego i śmiertelności wewnątrzszpitalnej. TIA było częściej obecne w grupie II.

Wnioski: Podczas dekady zaobserwowano poprawę wykrywalności głównych modyfikowalnych czynników ryzyka udaru oraz redukcję korzystania z używek, co doprowadziło do wzrostu wieku, w którym wystąpił udar mózgu. Wykrywalność i postępowanie z czynnikami ryzyka udaru w profilaktyce pierwotnej w grupie polskich pacjentów z udarem poprawiły się podczas analizowanego okresu.

Słowa kluczowe: czynniki ryzyka, udar mózgu, epidemiologia, profilaktyka.

\section{PURPOSE}

Stroke is the third cause of death, following the coronary heart disease (CHD) and cancers, and is the first cause of permanent disability in adults, especially after 60 years of age. Despite the fact that stroke can affect youths, as much as $3 / 4$ of first-ever ischemic stroke regards patients after 65 years [1].

The incidence of ischemic stroke in Poland amounts to 119.3 cases per 100,000 population in men and 107.8 cases per 100,000 in women, which is higher than in the European population (114.7 and 74.9 respectively) [2]. The worldwide burden of ischemic stroke indicates a 37\% increase that occurred between 1990 and 2010. There are discrepancies in available data regarding the effect of income level in a particular country on stroke incidence. The ischemic stroke incidence decreased in high-income countries by $13 \%$ and remained stable in low and middleincome countries [3].

The significance of stroke in the society is connected with high mortality and disability. After one year after stroke, $37 \%$ of patients are disabled [4].

Pathogenesis of particular stroke types is connected with risk factors. The classic risk factors may be divided into non-modifiable, such as age, sex, race, and genetic background, and modifiable ones, which mainly include hypertension, atrial fibrillation (AF), CHD, diabetes, cigarette smoking, excessive drinking, dyslipidemia, atherosclerosis, and cardiac defects [5]. Potentially modifiable risk factors are responsible for up to $90 \%$ of stroke occurrences [6]. Most of the risk factors of ischemic stroke have similar impact on both atherothrombotic and embolic stroke, which may indicate one possible common pathomechanisms [1, 7]. Better knowledge of stroke risk factors determines the use of proper primary and secondary prevention. Targeted interventions that reduce blood pressure, smoking or excessive drinking and promote physical activity and a healthy diet could substantially reduce the burden of stroke [6]; however, there is a trend observed toward increasing stroke incidence at younger age $[8,9]$.

The aim of the study was to establish the premorbid detection of ischemic stroke risk factors in a population of stroke patients in Szczecin throughout a decade.

\section{METHODS}

Consecutive ischemic stroke patients, including transient ischemic attack (TIA), hospitalised in the Department of Neurology in Poland, were evaluated retrospectively. Group I consisted of patients hospitalised between 2003 and $2005(n=1524)$, whereas group II consisted of patients referred to hospital between 2013 and 2014 $(n=869)$.

Patients were Caucasians living in Szczecin and the surrounding areas. The diagnosis of ischemic stroke was made upon clinical examination, computed tomography or magnetic resonance imaging. The diagnoses were made on the basis of past medical history. The diagnoses of certain disorders were established during hospitalisation according to definitions as follows. Hypertension was described as blood pressure $\geq 140 / 90 \mathrm{~mm} \mathrm{Hg}$ detected at least three times. Diabetes was defined as fasting blood glucose level $>125 \mathrm{mg} / \mathrm{dl}$ or random blood glucose $>200 \mathrm{mg} / \mathrm{dl}$ [10]. The atrial fibrillation (AF) meant both persistent and paroxysmal detected in regular ECG or 24 hours-ECG examination. Fasting lipids blood level was measured on the second day of hospitalisation with dyslipidemia definition as LDL-C level $\geq 115 \mathrm{mg} / \mathrm{dl}$, HDL-C $\leq 40 \mathrm{mg} / \mathrm{dl}$ in men and $\leq 48 \mathrm{mg} / \mathrm{dl}$ in women and $\mathrm{TG} \geq 150 \mathrm{mg} / \mathrm{dl}$ [11]. Atherosclerotic changes in common or internal carotid arteries were detected using GE LOGIQ Book XP camera with linear head 7.5 MHz in group I and Esaote MyLab Twice linear head $18 \mathrm{MHz}$ in group II. The alcohol abuse was set as drinking of $>2$ standard drinks per day [12]. Smoking status was assessed according to the obtained history. 
Detection of stroke risk factors over the decade in the Polish population of ischemic stroke patients

Wykrywalność czynników ryzyka udaru na przestrzeni dekady w polskiej populacji pacjentów z udarem niedokrwiennym mózgu

\section{Statistical analysis}

The primary objective of this trial was to investigate the null hypothesis that in the period between 2003 and 2014, there was no significant improvement in the diagnostic procedures of the main stroke risk factors in Szczecin district patients. The alternative hypothesis was that during the analysed period, the abovementioned diagnostic procedures significantly improved.

There were two main types of variables assessed, i.e. measurement and nominal variables. To assess the equality of variances for the variables (age and NIHSS score), the Levene's test was used before the comparison of means. The test showed significance level $(p<0.001)$. For this reason and because of the skewness and non-normality of the distributions between variables (ShapiroWilk test), the results were presented as number (percentage) for qualitative variables or median for quantitative variables. Data were compared between groups using the nonparametric Mann-Whitney $U$ test for continuous variables and for using the nonparametric $\chi^{2}$ test for categorical variables. All statistical tests were two-tailed; $p<0.05$ was considered to indicate the statistical significance. The analysis was performed with STATISTICA 12 software (StatSoft, USA).

\section{RESULTS}

The mean age of population in group I was 70 years as compared to 74 in group II $(p<0.001)$. The percentage of men was significantly higher in group I ( $53.5 \%$ vs. $38.5 \%$ respectively, $p<0.001)$. The higher education as compared to others was not different between groups $(p=0.89)$.

The initial NIHSS score on stroke onset was not statistically significant between the groups (group I: median 8.0 vs. group II: median 7.0, Mann-Whitney $U$ test, $p=0.6874)$.

The death rate during hospitalisation did not change throughout the decade, either $(141-9.3 \%$ in group I; $106-12.2 \%$ in group II; $\chi^{2}$ test, $\left.p=0.0876\right)$.

The duration of hospitalisation was greater in group I (group I: mean 13.7 days, $\min 1, \max 55, \mathrm{SD} 7.61$; group II: mean 12.9 days, $\min 1, \max 123$, SD 13.7; Mann-Whitney $U$ test $p<0.001)$.

TIA was more common in group II (109 patients, $12.5 \%$ ) vs. group I (81 patients, 5.3\%); Mann-Whitney $U$ test $p<0.001)$.

\section{DISCUSSION}

In the present study, the authors assessed the frequency of detection of ischemic stroke risk factors in the population of Poles living in Szczecin throughout a decade. In the subject population, the mean age of stroke significantly increased from 70 to 74 years. There are con-
Table 1. The pre-hospital frequency of ischemic stroke risk factors and parameters

\begin{tabular}{|l|c|c|c|}
\hline Parameter & $\begin{array}{c}\text { Group I: } \\
n=1524(\% ; n)\end{array}$ & $\begin{array}{c}\text { Group II: } \\
n=869(\% ; n)\end{array}$ & $\begin{array}{c}p \\
\left(X^{2} \text { test }\right)\end{array}$ \\
\hline Hypertension & $60.6 ; 924$ & $84.9 ; 738$ & $<0.001$ \\
\hline Coronary heart disease & $35.3 ; 538$ & $54.1 ; 470$ & $<0.001$ \\
\hline Atrial fibrillation & $15.8 ; 241$ & $34.3 ; 298$ & $<0.001$ \\
\hline Diabetes & $21.1 ; 322$ & $26.6 ; 231$ & 0.002 \\
\hline Dyslipidemia & $32.3 ; 493$ & $42.5 ; 369$ & $<0.001$ \\
\hline $\begin{array}{l}\text { Carotid arteries } \\
\text { ultrasonography }\end{array}$ & $2.9 ; 45$ & $6.2 ; 54$ & $<0.001$ \\
\hline $\begin{array}{l}\text { Significant carotid } \\
\text { artery stenosis }(\geq 50 \%)\end{array}$ & $0.7 ; 10$ & $1.5 ; 13$ & 0.65 \\
\hline
\end{tabular}

Table 2. The in-hospital frequency of ischemic stroke risk factors and parameters

\begin{tabular}{|l|c|c|c|}
\hline Parameter & $\begin{array}{c}\text { Group I: } \\
\boldsymbol{n}=1524(\% ; \boldsymbol{n})\end{array}$ & $\begin{array}{c}\text { Group II: } \\
\boldsymbol{n}=\mathbf{8 6 9}(\% ; \boldsymbol{n})\end{array}$ & $\begin{array}{c}\boldsymbol{p} \\
\left(\mathbf{X}^{2} \text { test) }\right.\end{array}$ \\
\hline Hypertension & $8.4 ; 128$ & $7.4 ; 64$ & 0.37 \\
\hline Coronary heart disease & $6.9 ; 106$ & $3.2 ; 28$ & 0.1698 \\
\hline Atrial fibrillation & $5.2 ; 79$ & $10 ; 87$ & $<0.001$ \\
\hline Diabetes & $9.25 ; 141$ & $3.8 ; 33$ & $<0.001$ \\
\hline Dyslipidemia & $26.5 ; 404$ & $19.6 ; 170$ & $<0.001$ \\
\hline $\begin{array}{l}\text { Significant carotid } \\
\text { artery stenosis }(\geq 50 \%)\end{array}$ & $5.4 ; 82$ & $17.4 ; 151$ & $<0.001$ \\
\hline
\end{tabular}

Table 3. The frequency of alcohol abuse and smoking

\begin{tabular}{|l|c|c|c|}
\hline Parameter & $\begin{array}{c}\text { Group I: } \\
n=1524\end{array}$ & $\begin{array}{c}\text { Group II: } \boldsymbol{n}) \\
n=869(\% ; \boldsymbol{n})\end{array}$ & $\begin{array}{c}\boldsymbol{p} \\
\left(\mathbf{X}^{2} \text { test }\right)\end{array}$ \\
\hline Excessive drinking & $5.1 ; 78$ & $3.9 ; 34$ & $<0.01$ \\
\hline Smoking & $48.9 ; 746$ & $37.7 ; 328$ & $<0.001$ \\
\hline
\end{tabular}

trary results available in different studies. The mean age at stroke onset tended to decrease in the US population between 1995 and 2005, but only in black race population it was statistically significant [8]. During the period from $1993 / 1994$ to 2005 , the mean age at stroke onset in the USA decreased from 71.2 to 69.2 [9].

Our observation regarding the predominance of male sufferers in the first group is inconsistent with other analyses. This difference may result from the fact that Polish income and healthcare system systematically has been improving, which may have had a positive influence especially on male's health. The standardised death ratio in men in Poland throughout the last 20 years has been falling in a greater extent as compared to women $[8,13,14]$.

The identification of risk factors in the prevention of stroke throughout the period from 2003 to 2005 and from 2013 to 2014 was significantly higher in the latter period. This concerns hypertension, $\mathrm{CHD}, \mathrm{AF}$, type 2 diabetes, dyslipidemia. The pre-hospital diagnosis of particular risk factors consequently leads to lower rate of in-hospi- 
tal detection that was observed in diabetes and dyslipidemia, whereas in-hospital detection of hypertension and $\mathrm{CHD}$ did not change. There are studies where the history of hypertension and AF was stable during one and two decades, whereas in neighbourhood countries as Lithuania the awareness and detection of hypertension was also increasing $[15,16]$. The noteworthy is fact that $\mathrm{AF}$ in our population was diagnosed significantly more often before the stroke onset between 2013 and 2014 and there was additionally a positive tendency reflected by higher rate of in-hospital diagnosis in this period. Our results suggest that there more attention was paid to diagnose efficiently and treat this serious risk factor that is responsible for more than $20 \%$ of strokes [17]. The explanation may also be the more common use of 24-hour monitoring ECG, but we did not analyse this parameter.

Beside the positive trend in the diagnosis of risk factors in prevention of stroke, we also noted substantial reduction in excessive drinking and smoking. Changes in smoking habits differ between populations that were analysed elsewhere. In the Oxfordshire population, in United Kingdom, between periods of 1981-1984 and 2002-2004, a reduction there was observed, whereas between periods 1986-1987 and 2006-2008 in the Kaunas population of Lithuania significantly opposite tendency was detected $[18,19]$.

Despite the improvement in detection of risk factors in primary prevention and positive changes in habits, we did not observe significant changes in neurological deficit on admission and at discharge; either, no changes were observed in in-hospital mortality. The positive tendency of better diagnosis of main stroke risk factors may diminish the risk of stroke events, but it doesn't influence the severity of stroke.

We included in our analysis both TIA and stroke patients. This method seems to be reasonable because these identities are similar in regard to risk factors and pathogenesis. Moreover, previously diagnosed TIA patients could be diagnosed as stroke according to the present definition of TIA. In the analysed groups, the incidence of TIA was significantly more often present in group II. The possible explanation of this finding is the increase in the physicians' awareness of the further stroke risk in such patients. In a nowadays practice, most of the TIA patients are admitted to the hospital.

We observed a positive trend during the analysed periods within the frequency of pre-admission carotid arteries ultrasound performance, but the percentage remains still at the unsatisfactory level (2.9\% vs. $6.2 \%$ ). During hospitalisation, we detected higher rate of significant carotid artery stenosis ( $5.4 \%$ vs. $17.4 \%)$. The explanation may be the use of higher quality ultrasonography equipment and that the physicians performing this examination were more experienced. The increasing age of our population may also add to the explanation of such observations because the atherosclerosis progresses within the age.

The difference in duration of hospitalisation between groups is significant. The reason may be more efficient treatment or the positive trends in stroke risk factors detection and possibly their treatment.

The limitation of this study is the difference in the size between the groups.

\section{CONCLUSIONS}

A historical higher frequency of stroke incidence in Poland as compared to western countries may be due to insufficient risk factors identification and stroke prophylaxis [2]. During twelve years, we observed a positive trend towards better detection of the main modifiable stroke risk factors, including the reduction in habits frequency that caused the significant increase in the age at stroke onset. We conclude that the improving level of public health has led to positive epidemiological trends in Polish stroke patients. More efforts should be made in the future to intensify such positive changes.

\section{Conflict of interest/Konflikt interesu}

Absent./Nie występuje.

Financial support/Finansowanie

Absent./Nie występuje.

References/Piśmiennicłwo

1. Kotlęga D, Białecka M, Kurzawski M, Droździk M, Gołąb-Janowska M, Ciećwież S, Nowacki P. The effects of simvastatin on the $\mathrm{C}$-reactive protein level and lipid profile in the acute phase of ischaemic stroke in relation to -717A>G CRP gene polymorphism. Pomeranian J Life Sci 2017; 63: 22-26. 
2. The European Registers of Stroke (EROS) Investigators: Incidence of stroke in Europe at the Beginning of the $21^{\text {st }}$ Century. Stroke 2009; 40: 1557-1563.

3. Krishnamurthi RV, Feigin VL, Forouzanfar MH, Mensah GA, Connor M, Bennett DA, et al. Global Burden of Diseases, Injuries, Risk Factors Study 2010 (GBD 2010); GBD Stroke Experts Group: Global and regional burden of first-ever ischaemic and haemorrhagic stroke during 1990-2010: findings from the Global Burden of Disease Study 2010. Lancet Glob Health 2013; 1: e259-e281.

4. Appelros P, Nydevik I, Viitanen M. Poor outcome After First-Ever Stroke. Predictors for Death, Dependency, and Recurrent Stroke Within the First Year. Stroke 2003; 34: 122-126.

5. Sacco RL, Adams R, Albers G, Alberts MJ, Benavente O, Furie K, et al. Guidelines for Prevention of Stroke in Patients With Ischemic Stroke or Transient Ischemic Attack: A Statement for Healthcare Professionals From the American Heart Association/American Stroke Association Council on Stroke: Co-Sponsored by the Council on Cardiovascular Radiology and Intervention: The American Academy of Neurology affirms the value of this guideline. Stroke 2006; 37: 577-617.

6. O’Donnell MJ, Xavier D, Liu L, Zhang H, Chin SL, Rao-Melacini P, et al. Interstroke investigators: Risk factors for ischaemic and intracerebral haemorrhagic stroke in 22 countries (the INTERSTROKE study): a case-control study. Lancet 2010; 376: 112-123.

7. Ohira T, Ahahar E, Chambless LE, Rosamond WD, Mosler TH, Folsom AR. Risk factors for Ischemic Stroke Subtypes. The Atherosclerosis Risk in Communities Study. Stroke 2006; 37: 2493-2498.

8. Kleindorfer DO, Khoury J, Moomaw CJ, Alwell K, Woo D, Flaherty ML. Stroke Incidence Is Decreasing in Whites But Not in Blacks. A Population-Based Estimate of Temporal Trends in Stroke Incidence From the Greater Cincinnati/Northern Kentucky Stroke Study. Stroke 2010; 41: 1326-1331.

9. Kissela BM, Khoury JC, Alwell K, Moomaw CJ, Woo D, Adeoye O. Age at stroke: Temporal trends in stroke incidence in a large, biracial population. Neurology 2012; 79: 1781-1787.

10. Goldstein LB, Bushnell CD, Adams RJ, Appel LJ, Braun LT, Chaturvedi S. Guidelines for the Primary Prevention of Stroke: A Guideline for Healthcare Professionals From the American Heart Association/American Stroke Association. Stroke 2011; 42: 517-584.

11. Reiner Z, Catapano AL, De Backer G, Graham I, Taskinen MR, Wiklund O, et al. ESC/EAS Guidelines for the management of dyslipidaemias: the Task Force for the management of dyslipidaemias of the European Society of Cardiology (ESC) and the European Atherosclerosis Society (EAS). Eur Heart J 2011; 32: 1769-1818.

12. Khan NA, Quan H, Hill MD, Pilote L, McAlister FA, Palepu A, et al. Risk factors, quality of care and prognosis in South Asian, East Asian and White patients with stroke. BMC Neurol 2013; 13: 74.

13. Life Expectancy Tables Of Poland 2015. Central Statistical Office of Poland. Available at: www.stat.gov.pl (Accessed: 2.05.2018).

14. Mozaffarian D, Benjamin EJ, Go AS, Arnett DK, Blaha MJ, Cushman M, et al. American Heart Association Statistics Committee and Stroke Statistics Subcommittee. Heart disease and stroke statistics - 2015 update: a report from the American Heart Association. Circulation 2015; 131: e29-e322.

15. Benatru I, Rouaud O, Durier J, Contegal F, Couvreur G, Bejot Y, et al. Stable stroke incidence rates but improved case-fatality in Dijon, France, from 1985 to 2004. Stroke 2006; 37: 1674-1679.

16. Reklaitiene R, Tamosiunas A, Virviciute D, Baceviciene M, Luksiene D. Trends in prevalence, awareness, treatment, and control of hypertension, and the risk of mortality among middle-aged Lithuanian urban population in 1983-2009. BMC Cardiovasc Disord 2012; 12: 68.

17. Gołąb-Janowska M, Meller A, Kotlęga D, Bajer-Czajkowska A, Nowacki P. Atrial fibrillation and stroke - Coexistence and attitude to preventive therapy on the basis of Szczecin and Szczecin region patients. Neurol Neurochir Pol 2014; 48: 410-415.

18. Rothwell PM, Coull AJ, Giles MF, Howard SC, Silver LE, Bull LM, et al. Oxford Vascular Study: Change in stroke incidence, mortality, case-fatality, severity, and risk factors in Oxfordshire, UK from 1981 to 2004 (Oxford Vascular Study). Lancet 2004; 363: 1925-1933.

19. Radisauskas R, Malinauskiene V, Milinaviciene E, Kranciukaite-Butylkiniene D, Tamosiunas A, Bernotiene G, et al. Trends in the Attack Rates, Incidence, and Mortality of Stroke during 1986-2012: Data of Kaunas (Lithuania) Stroke Registry. PLoS One 2016; 11: e0153942. 